\title{
COGNITIVE-PRAGMATIC ASPECT OF THE CATEGORY OF EVALUATION
}

\author{
Ganna Prihodko \\ DSc, Professor, Zaporizhzhia National University, Ukraine \\ e-mail: anna.prikhodko.55@gmail.com,orcid.org/0000-0001-6220-5333 \\ Oleksandra Prykhodchenko \\ PhD, Zaporizhzhia National University, Ukraine \\ e-mail: prihodchenkoaleksandra@gmail.com, orcid.org/0000-0002-8468-2453
}

\section{Summary}

The paper is aimed at studying the category of evaluation, a very important and interesting phenomenon in linguistics. Evaluation of different world's fragments is, of course, a considerable part of human cognitive activity. Evaluation is realized by subject's consciousness in the perception and processing of information about the outside world and relates to internal (linguistic) world of man, reflecting his "view of the world." The essence of the category of evaluation is explained by the theory of value orientation of person's activity and consciousness, and the range of its characteristics embraces all that is given by the physical and mental nature of man, his being and feeling. Evaluation is as a kind of cognitive activity, as in epistemological terms, any cognitive act expresses the attitude of the speaker to the object described, that is, contains an act of evaluation. Evaluative interpretation of circumstances, subjects is one of the most important types of mental-speech activity in everyday life of an individual. The article proposes the communicative approach to the research of evaluative phenomena that exist in the reality and are reflected in language. The communicative aspect of the language means the existence of a unified structure of the linguistic units, bound by the connection of meaningful and formal sides. In this regard, the functioning of evaluative utterances acquires special significance, because the evaluation of various fragments of the world is one of the most important components of individual's cognitive activity. The evaluation should be studied comprehensively and profoundly as a category of high level abstraction as one of the categories given by the social, physical and mental nature of a person, which determines his relation to other individuals and objects of the surrounding reality.

Keywords: world view, cognitive activity, value, language functions, communication, pragmatic.

\section{DOI: https://doi.org/10.23856/3812}

\section{Introduction}

The study of linguistics at the present stage includes all aspects of speech activity and speech interaction. It is known that, speech activity is an abstraction, which does not correlate directly with other activities. This activity occurs only when speech is self-sufficient, when its motive can not be satisfied in any other way than speech. In this regard, the problem of correlation of speech activity and communication is of current interest (Toolan, 2013). The cognitive-pragmatic aspect of linguistics is comparatively young, but is dynamically developing. It puts the focus not only on the language in the inseparable unity of its form and essence, but also on higher unity, namely, the correlation between language and individual who acts in the real world, thinks and perceives the environment, communicates with other persons. 
It should be noted that when we talk about the cognitive-pragmatic aspect of mastery of language or language skills, we mean, above all, the orientation to the interlocutor.

Therefore, it can be asserted that the notion of language began to be understood more broadly than it was inherent in structural and generative linguistics. Triad form - meaning function connects language with extra lingual activities and with the conditions of its use in human activities. Multidimensionality, of language organization allows it to be simultaneously turned to the external reflected reality and to the area of human mentality. Achieving any pragmatic goals is impossible without communication, so the latter is perhaps the most important condition of person's activity and life itself (Lulu, 2017: 564). Verbal communication is carried out through a language, which is both a form and a means of communication.

The realization $\mathrm{n}$ of the linguistic system takes place in the process of communication. This organism is not abstract; it actually exists in the minds of interlocutors and can not be materialized outside communication. In this regard, the integrated investigation of language as one of the fundamental principles of human relations is of great importance (Anderson, 2011). The decision of this question is the domain of communicative linguistics, which studies the language at all its levels and in and a variety of functional representations. This fact promotes mutual understanding between people.

The possibility of verbal communication is always realized in a definite situation, in a certain context, which is an internal characteristic of communication. The communicative aspect of the language means the existence of a unified structure of the linguistic units, bound by the connection of meaningful and formal sides (Bara, 2010).

It becomes apparent that the communicative approach involves interweaving with the cognitive approach. In this regard, the functioning of evaluative utterances acquires special importance, because the evaluation of different fragments of the world is one of the most essential components of individual's pragmatic and cognitive activity (White, 2016: 77-96).

The object of this article is the study of the category of evaluation as a linguistic phenomenon. The subject is pragmatic and cognitive aspects of evaluative utterances in modern English fiction. The aim of this paper is to establish the role of assessment in the process of manifestation and perception of objective reality

\section{Data and methodology}

Methodology is determined by the objectives, the material, theoretical theses of the paper. It integrates the main principles of the cognitive theory and theory of communication. The methodology employed in the study is Evaluation theory, which presents basic notions for the linguistic analysis. Focusing chiefly on semantic peculiarities of evaluation, this theory broadens the borders of the analysis with discourse semantics. It means that all aspects of communication (register, mood, participants with their pragmatic purposes and cognitive systems) become very significant for the study of establishing and targeting evaluation. In this respect, the theoretical viewpoint essential to the research is also the pragmatic approach to evaluation analysis (Arutyunova, 2012; Prihodko, 2016; Volf, 2009) focusing on the role of extralinguistic knowledge in utterance interpretation and the principles that constrain its use as well as on the context types for evaluation. Speech act analysis is used while studying the pragmatic characteristics of utterances containing evaluative concepts.

The material, which is subjected to analysis, was a selection of approximately 350 utterances of the works by contemporary British and American writers. The criterion of the selection was the existence of evaluative words in the utterance. 


\section{The essence of the category of evaluation}

Evaluation is usually defined as speaker's objective or subjective stance to certain objects, things, phenomena that are explicitly or explicitly expressed by different language means (Prihodko, 2016: 17).

Evaluation is as a kind of cognitive activity, as in epistemological terms, any cognitive act expresses the attitude of the speaker to the object described, that is, contains an act of evaluation (Breeze \& Olza, 2017; Martin \& White, 2005). The evaluative moment is nothing but a person's mental operation held on the subject of utterance (perception, understanding, synthesis, conclusion, etc.), which is an evaluation in its broadest sense.

All environmental phenomena perceived by man have a certain value in our minds, that is, they can be assessed. Evaluation is a fundamental constituent of cognition, which is based on a value approach to the phenomena of nature and society. So, person's activity and life as a human being having diverse needs, interests and goals is impossible without evaluation.

People appraise their past and present, appearance and behavior of the individual, the shape and size of various subjects, things, duration and frequency of events, the degree of complexity of tasks, etc. Evaluative explanation of circumstances, subjects is one of the most important types of mental-speech activity in everyday life of an individual.

In the evaluative utterance the speaker accents or highlights exactly, what he thinks is relevant at the moment. As a result, the objective reality is viewed by an individual from the point of view of its evaluative character - good and evil, truth and falsehood, justice and injustice, benefit and harm, beauty and ugliness.

Evaluation is based on the logical notion of "value". Genesis of the notion of "value", if we resort to reconstructing it on the basis of the etymology of the words it is named, fixes in it at least three essential elements: the characterization of the external properties of objects and things as phenomena of evaluative attitude to them; psychological qualities of the person as a subject of this attitude; relations between people, their communication, due to which values acquire a generalized meaning.

Value is a positive or negative property of the objects of the surrounding world for the speaking community. This significance of these properties is determined not by the objects' features as such, but by their role in the life of an individual language speaker and in the life of the speaking community in general.

Each of the classes of values combines the fundamental meaning of value its material-objective, psychological and social significance. By recognizing the natural properties of objects and reproducing their value, an individual reveals certain aspects of social relations, because the significance of a thing or phenomenon is determined primarily by the social attitude towards them.

There are universal values (common to all mankind, peculiar to individual communities) and individual ones. Being a concentrated expression of the experience of the vital activity of a particular social community values form a certain system, which an individual as a member of this society adheres to in the process of self-evaluation.

Personal values are an individual reflection of group or universal values. They are somewhat diverse in different people, due to the interpretation of their content and the shift of emphasis. The selection, appropriation and assimilation of social values by an individual are mediated by his social identity and the values of the small contact groups referenced to him.

The subject of evaluation acts in these cases as a mental or physical receptor, evaluating event, situation and object in different ranges: ethical evaluation (embarrassing, humiliating, 
sinful), emotional (boring), intellectual (foolish), utilitarian (meaningless, late) and psychological (difficult, easy, not easy, wise). It emphasizes the most important feature of the semantics of evaluative words, their diffuse meaning, primarily due to the ability to represent evaluation in terms of different grounds.

\section{Pragmatic and cognitive character of evaluation}

Human activity is a pragmatic concept. It is appropriate only when it is directed at those phenomena and properties from which it is possible to obtain something useful and valuable. As rightly remarks N. Arutyunova, the nature of the evaluation always corresponds to the nature of man, because we evaluate only "what is needed (physically and spiritually) to man and to Mankind" (Arutyunova, 2012: 181).

Evaluation is always cognitive in its nature, and hence logical-subject. Evaluative and epistemological functions of the language are closely interrelated and interconnected. Moreover, at the same time, they are equal, as in the process of evaluation, cognition is transformed, and in the process of cognition, evaluation is always present.

The relationship between cognition and evaluation is very complex. It belongs to the field of cognitive linguistics, the problems of which cover the nature of the procedures that regulate and structure the speech perception. Thus, the cognitive approach based on the interaction of language and thinking is the most relevant for investigation of the category of evaluation, because it studies it in the context of human cognitive activity.

Evaluation is a process that is characteristic of any science. This is confirmed by the fact that value orientation in many cases contributed to the development of a whole range of directions not only in the linguistic field, but also in computer technology, genetic engineering, and many other areas. It indicates stable integration of scientific knowledge within the cognitive paradigm that was formed as interdisciplinary (cognitive) science (White, 2015).

The cognitive process of evaluation, including in the general program of human activity, is decision-making-oriented, and is the basis of the choice of practical actions. A person as a subject of linguistic activity is an individual who perceives and comprehends the world, and is capable of evaluating speech facts in his day-to-day speech practice.

The aesthetic experience of the individual is mainly recorded in the evaluative definitions of words.

The pragmatic aim put forward by the speaker is to convey to the listener his point of view, to convince him of the possibility and legitimacy of precisely this, and not another vision of the word in the best possible way. The image of the word, which is stored in the linguistic consciousness of the individual, is revealed in emotional and aesthetic evaluations. It is known that this method is based on associations, caused by the phenomenon reflected in the word, or by its sound form.

Furthermore, by this time, Vinogradov's judgments that the word is shining with the expressive colors of the social environment have not lost their relevance. The linguist wrote, that "by displaying the personality (individual or collective) of the subject of speech, characterizing his evaluation of reality, a word qualifies him as a representative of a particular social group. Expression is always a subjective, typical and individual from the fastest to the most stable, from the excitement of the moment to the continuity not only of the person and her neighboring environment, class, but also of the epoch, nation and culture" (Vinogradov, 2001: 25).

Estimation is anthropocentric by its nature. While assessing an object or thing, a person must "pass" its signs through his consciousness (Bednarek, 2009: 146-175). The content of the 
evaluation reflects the nature of the person. We always evaluate only those things that we need. Appraisal represents a person as a goal, showing the movement from the sphere of systems to the center of all these systems, to a person, as a language personality.

The close connection between the speaker's evaluation and his knowledge of the world is confirmed by the fact that in the utterance an evaluation can find its expression in the characterization of certain events, objects, phenomena that have a positive / negative evaluative significance for a particular social group or society as a whole.

The linguistic aspect of the category of evaluation constitutes the whole set of means and methods of its expression. They are phonetic, morphological, syntactic, mental, etc., which reflect the elements of the evaluative situation.

Stratification of the evaluation vocabulary reaffirms A. Potebnya's judgment about the parts of speech as a kind of "modus" (Potebnya, 1968: 5) the representation of something in our consciousness, as well as the opinion of some scholars on the necessity for a functional-cognitive approach to the study of the category of evaluation (Arutyunva, 2012; Byessonova, 2012; Myroniuk, 2017; Nikitin, 2007; Volf, 2009). The interest of researchers in the "grammar of evaluation" is stimulated by the characteristic for contemporary linguistics atmosphere of attention to functional grammar, which reliably occupied its niche, despite less than centuries-old history.

Functional orientation of evaluative utterances is caused by the fact that the speaker uses language means as a device for his own intrusion into a speech act, as an expression of his thoughts, his attitude and his evaluation, the expression of relations he establishes between himself and the listener.

It is the evaluative-pragmatic function of the language, which is opposed to the representative (or conceptual) one. Similar opinion is expressed by Sh. Bally, who emphasized that "to think means respond to the submission, stating its presence, evaluating it or requesting it" (Bally, 1955: 43). The speaker in this way expresses either the manifestation of the will or judgment of the fact or the values of the fact.

As a result, the notion of "function" is fundamental in the study of linguistic units: "this is ... the ability to perform a certain purpose, the potential of functioning (in a "reduced form"), and at the same time the realization of this ability, that is, the result, the purpose of functioning" (Bondarko, 1999: 26). Functional principle allows to see evaluative utterances in their "actions", reflecting positive or negative values, attributed to the subject of the object of evaluation.

Based on the tasks of functional grammar - the development of the dynamic aspect of functioning of grammatical units in interaction with elements of different levels of language, which participate in expressing the meaning of the utterance, linguists try to explore comprehensively the semantics of evaluation and means of its expression in modern linguistic studies.

\section{Interconnection of context and evaluative utterance}

Modern linguistics emphasizes the dynamic connection between the meaning of a word and its context (Fedoriv, 2016: 1-36; Kecskes, 2013). Context provides an opportunity to reveal its hidden potential. Words encode previous experience and former contexts of the use of a given word or expression. In the act of communication, the old clashes with the actual one. The actual communicative meaning is generated as a result of a collision in the coded lexical units of the "old", previous contexts and the actual situational context in which this utterance is used. The personal contexts of the speaker and hearer, encoded in the same words based on personal experiences or in the same linguistic expressions, often differ. 
All said above gave opportunity to establish three types of interconnection between the context and evaluative utterance: uation;

1) the context influences the evaluative utterance, changing the character of the eval-

2) the evaluative utterance affects the context by adding the evaluative component to its structure;

3) the mutual influence of the evaluated utterance and context.

Consider the mechanism of mutual influence of the context and the evaluative utterance in detail.

In the first type of interdependence, two variants are possible - negative and positive.

In a negative context, an evaluative utterance (positive or negative) has a negative connotation. If, there are no semes with negative evaluation in the lexemes that are part of the utterance, they are added to the semantic structure of words under the influence of the context:

(1) "Poor little rich girl", I said savagely" (Christie, 1967: 86).

In this utterance, the lexeme little is undoubtedly has evaluative seme, but the word poor is perceived more vividly, in contrast to the word rich, although it is not its antonym in this context. The negativity of the entire context is predetermined by the use of the word savagely (fiercely, roughly), which, in contrast to the word little, serves rather to express the intensity of the evaluation than to qualify its character It also contributes to the appearance of negative-evaluative impulses in the semantic structure of the words that make up this utterance.

Here is another example that illustrates the impact of context on the mark of evaluation:

(2) "How nice to you, Cindy told him with pseudo-sweetness that it's not just dull old delegations who come to you with problems" (Hailey, 1968: 103).

The word old deprived of its nominative meaning, serves here to express the negative qualification of the subject of the utterance (disapproval, ridicule), which is revealed as a result of its use next to the lexeme dull (boring annoying), which expresses negative evaluation. It is necessary to mention that the ironic use of nice is restrained in the same way, which is emphasized by the usage of the word pseudo-sweetness and the plural of noun delegations in the meaning of the singular.

In a positive context, an evaluative utterance with a neutral or negative evaluation acquires positive connotation, adding to its semantic structure semes of occasional positive evaluation under the influence of the context. It takes place because some pejoratives in a certain context may express the opposite evaluation due to their ambivalence. In these cases, the descriptive semantic features of words do not agree with their evaluative trait:

(3) "Listen. Listen, you little fool! You deserve a hundred lashes. Are you going to ruin things now by mindless stupid jealousy? I'm here Ilove you, you are my wife" (Murdoch, 1974: 78).

In this utterance the negatively colored words fool, stupid, jealousy are used to enhance the pragmatic effect of the positive evaluation. This becomes possible due to the fact that the positive context indicates the unreasonableness of the addressee's disturbance.

In the second case, it is possible to distinguish two types of interaction between the context and the evaluative utterance:

1) the context (neutral or positive) combines in the utterance lexemes with negative-evaluative semes, under the influence of which the context becomes negative:

(4) "Opening it (the door), I beheld a handsomely ugly face, animal and engaging" (McInnes, 1958: 71).

In this utterance, we observe a combination of an objective characteristic of a person, expressed with the help of the adjective $u g l y$, and emotionally-subjective expressed by the 
adverb handsomely. The phrase of this type is not always an oxymoron in the conventional sense because the lexemes that make it up are not necessarily antonyms. Their peculiarity is precisely in the fact that a word, which usually expresses a positive characteristic of a phenomenon or object, is used here to convey a negative evaluation.

2) the context (neutral or negative) due to the words with positive meaning in its structure reflects the positive sense of the utterance:

(5) "Old friend of my father's. Said it was good to have me abroad" (Vonnegut, 1952: 186).

The change in the evaluative perspective occurs under the influence of the general-evaluative predicate good the semantic structure of which contains semes of positive evaluation. The change in the estimated perspective occurs under the influence of the general-estimated good predicate, which contains seven positive assessments. It should be noted that the change in the speaker's opinion about the object of evaluation is influenced by the fact that integrated speech is incorporated into the direct speech as an evaluative element of the whole utterance.

In the third case, an interaction between the evaluative utterance and the context is observed.

The utterance contains appraisors with only positive semes in their semantic structure, and appraisors with only negative-evaluative semes. Interacting with the context, such utterance contributes to its transformation into a negative one (that is, the first two variants of the mutual influence of the evaluative utterance and the context seem to be combined here):

(6) "I left them working, the car looking disgraced and empty with the engine open and parts spread on the work bench, and went in under the shed and looked at each of the cars. They were moderately clean, a few freshly washed, the others dusty ... I looked at the tires carefully, looking for cuts or stone bruises. Everything seemed in good condition. It evidently made no difference whether I was there to look after things or not" (Hemingway, 1976: 40).

Describing the state of military equipment, the author uses words (epithets) with both a negative evaluation (disgraced, empty, dusty) and positive one (clean, freshly, good), which, interacting within the boundaries of the context, determine its negative perception. The negativity here is also emphasized by the last phrase of the utterance, which shows the hero's indifferent attitude to the phenomenon described.

It is impossible to overlook the fact that in this situation variants also are distinguished. If an utterance contains words with the positive evaluation, and the context conveys the negative one, then due to their interaction, the weakening of the negative evaluation of the context and the positive evaluation of the utterance takes place. Moreover, on the contrary, if the utterance includes words with the negative evaluation, and the context is positive (such cases are much less common than the previous ones), then the result of their interaction is the samethere is a weakening of both evaluative meanings.

\section{Conclusions}

The interpretation of the evaluation as a "super-subjective" category of intellection and language reflects the complex and contradictory nature of the evaluative semantics, which consists in generalizing reference of the evaluative function, "secondariness" of its nomination, the specificity of the communicative purpose, which reflects the objective properties of information simultaneously.

So we can understand the evaluation as an expression of the evaluative relation of the speaker to the subject of speech, achievable at all levels of the language, which is the result of abstract work of the speaker's consciousness, logical reasoning. 
The concept of "evaluation" has become an integral part of the conceptual apparatus of modern linguistics, which clearly demonstrates the fact that it is impossible to examine a language without resorting to its primary purpose, its "creator", carrier, user, specific linguistic personality, a person.

To sum up, having focused the research on the area of the actualization of the evaluation in different types of context, we have submitted results of interconnection of context and evaluative utterance in the field of Pragmatics, Evaluation theory, theory of Text, and theory of linguistic and stylistic Context. Often, units that are neutral at the language level become evaluative in context. Such context can be called evaluative, as only within its boundaries the word acquires an evaluative meaning that is not inherent in its normative usage.

Our research shows that three types of interaction between the context and the evaluation utterance can be distinguished: the context affects the evaluative utterance, changing the mark of evaluation; the evaluative utterance influences the context, transforming the nature of its evaluation; the evaluative utterance and the context carry out organic mutual influence, and none of the parties prevails.

In conclusion, this study points out the necessity of the investigation of the evaluation in different types of context taking into account national stereotypes.

The evaluation, therefore, should be studied comprehensively and profoundly as a category of high level abstraction as one of the categories given by the social, physical and mental nature of a person, which determines his relation to other individuals and objects of the surrounding reality.

\section{References}

Anderson, J. M. (2011). Linguistic representation (Trends in linguistics: Studies and monographs). Berlin: Mouton de Gruyter.

Arutyunova, N. D. (2012). Logicheskij analiz yazyka. Adresatsiya diskursa [Logical analysis of the language. Discourse addressing]. Moscow: Indrik. [in Russian]

Bally, Sh. (1955). Obshaya lingvistika i voprosu frantsuzskogo yazyka [General linguistics and problems of French language]. Moscow: Izd-vo inostr. lit-ru. [in Russian]

Bara, B. G. (2010). Cognitive pragmatics: The mental processes of communication. USA: MIT Press.

Bednarek, M. (2009). Dimensions of evaluation: Cognitive and linguistic perspectives. Pragmatics and Cognition, 17(1), 146-175. Doi.: 10.1075/pc.17.1.05bed

Bondarko, A.V. (1999). Osnvu funktsionalnoj grammatiki: Yazykovaya interpretatsiya idei vremeni [Fundamentals of functional grammar: Linguistic interpretation of the idea of time]. St. Petersburg: Izd-vo S-Peterb. un-ta. [in Russian]

Breeze, R., Olza, I. (2017). Evaluation in media discourse. European perspectives. Berlin: Peter Lang. Doi.: 10.3726/b10531

Byessonova, O. (2012). Reconstruction of Value Concepts in the Language Model of the World. In: Ferencik, M. \& Bednarova-Gibova, K. (Eds.), Language, Literature and Culture in a Changing Transatlantic World II. Part I: Lingustics, Translation and Cultural Studies, 7-14.

Christie, A. (1967). Endless Night. London: Publ. by Collins.

Fedoriv, Ya. (2016). Speaking to the global audience: A case study into the message transformation. Lege artis. Language yesterday, today, tomorrow. I (2), 1-36. http://dx.doi.org/10.1515/ lart-2016-0009

Hailey, A. (1968). Airport. New York: Doubleday. 
Hemingway, E. (1976). A Farewell to Arms. Moscow, Russia: Progress Publishers.

Kecskes I. (2013). Intercultural Pragmatics. Oxford: Oxford University Press.

Lulu, L. (2017). Application of Cooperative Principle and Politeness Principle in Class Question-answer Process. Theory and Practice in Language Studies, 7 (7), 563-569. DOI: 10.17507/ tpls.0707.10.

Martin, J. R., White, P. R. R. (2005). The Language of Evaluation. Appraisal in English. New York: Palgrave Macmillan.

McInnes, C. (1958). City of Spades. New York: Macmillan.

Murdoch, I. (1974). The Sacred and Profane Love Machine. New York: Viking Press.

Myroniuk, T. (2017). Evaluative Responses in Modern English Fiction. Advanced Education, 8, pp. 103-108. DOI: 10.20535/2410-8286.108550.

Nikitin, M. V. (2007). Kurs lingvisticheskoj semantiki [Course of linguistic semantics]. St. Petersburg: Izd-vo RGPU im. A.I. Gertsena. [in Russian]

Potebnya, A. A. (1968). Iz zapisok po russkoj grammatike From notes on Russian grammar]. Moscow: Prosveshchenie. [in Russian]

Prihodko, A. (2016). Cognitive-communicative organization of the evaluative frame. Lege Artis, 1(1), pp. 275-308. DOI: 10.1515/lart-2016-0006 ISSN 2453-8035.

Prihodko, G. I. (2016). Katehoriia otsinky v konteksti zminy linhvistychnykh paradyhm [The category of evaluation in the context of the change of linguistic paradigms]. Zaporizhzhia: Kruhozir. [in Ukrainian]

Toolan, M. (2013). Narrative: A critical linguistic introduction. London; New York: Routledge Vinogradov, V.V. (2001). Russkij yazyk (Grammaticheskoye utseniye o slove) [Russian language: grammatical theory of the word]. Moscow: Nauka. [in Russian]

Volf, E.M. (2009). Funktsionalnaya semantika otsenki [Functional semantics of evaluation] (3d ed.). Moscow: Editorial URSS. [in Russian]

Vonnegut K. jr. (1952). Player Piano. - New York: Charles Scribner's Sons.

White, P. R. R., (2015). Appraisal Theory. In: Tracy, K. (Ed.). The International Encyclopedia of Language and Social Interaction.John Wiley \& Sons. Doi.: 10.1002/9781118611463.wbielsi041 White, P. (2016). Evaluative contents in verbal communication. In A. Rocci \& L. Saussure (Eds.), Verbal communication (pp. 77-96). Berlin, De Gruyter Mouton. Doi.: 10.1515/9783110255478-006. 